\title{
Multimodal signaling in Boana albopunctata (Anura: Hylidae): reading visual and acoustic cues
}

\author{
Andréa Rösel de Lourenço, Célio F. B. Haddad, and Fábio P. de Sá \\ Departamento de Biodiversidade and Centro de Aquicultura (CAUNESP), Instituto de Biociências, Universidade Estadual \\ Paulista Júlio de Mesquita Filho. Av. Vinte e Quatro A, 1515, 13506-900, Rio Claro, SP, Brazil. E-mail: fperin.sa@gmail.com.
}

\begin{abstract}
Multimodal signaling in Boana albopunctata (Anura: Hylidae): reading visual and acoustic cues. The acoustic mode of communication is important for anurans, but visual communication is beginning to be considered essential for some species, genera, and families. This study focuses on visual and acoustic signals in Boana albopunctata (Hylidae: Cophomantinae) in an attempt to increase our understanding of signaling in this nocturnal Neotropical treefrog. Visual signals were assessed to determine whether they are directed toward conspecific opponents, as has already been observed for some diurnal anurans, or associated with potential morphological asymmetries. Associations between visual and acoustic signals were explored. The results suggest that males may combine visual and acoustic signals (multimodal signaling) synergistically, thereby strengthening the efficiency of information transmission. Thus, in nocturnal anuran species, visual signals may function primarily as an alerting component and multimodal signaling may be a relevant way of communication.
\end{abstract}

Keywords: alerting function, territoriality, visual signaling.

\begin{abstract}
Resumo
Sinalização multimodal em Boana albopunctata (Anura: Hylidae): compreendendo os sinais visuais e acústicos. O modo de comunicação acústico é importante para os anuros, mas a comunicação visual está começando a ser considerada essencial para algumas espécies, gêneros e famílias. Ao investigar sinais visuais e acústicos, o objetivo deste estudo é a melhor compreensão da sinalização em Boana albopunctata (Hylidae: Cophomantinae), uma perereca noturna neotropical. Foi verificado se os sinais visuais são direcionados aos oponentes coespecíficos, como já observado para alguns anuros diurnos, ou se são relacionados a potenciais assimetrias morfológicas. Estudou-se também associações entre sinais visuais e acústicos. Esse estudo leva à compreensão de que os machos podem combinar sinergicamente sinais acústicos e visuais (sinalização multimodal), potencializando assim a eficiência da transmissão de informação. Conclui-se que para espécies noturnas de anuros os sinais visuais podem atuar como componentes de alerta e que a sinalização multimodal pode ser um meio relevante de comunicação.
\end{abstract}

Palavras-chave: função de alerta, sinalização visual, territorialidade.

Received 15 May 2020

Accepted 10 October 2020

Distributed December 2020 


\section{Introduction}

Acoustic communication is important for intraspecific interactions of anurans and has been widely studied. Calls are of central importance to social organization, such as advertisements for conspecifics and establishment of breeding territory limits (Wells 2010, Brunetti et al. 2014, Toledo et al. 2015, Chuang et al. 2017). Calls also play a fundamental role as prezygotic reproductive isolation mechanisms, thereby affecting the processes of speciation (Blair 1958, Doherty and Gehardt 1983, Gerhardt 1994, Grenat et al. 2013). Visual communication also has begun to be recognized an important and even essential component of intraspecific communication in anurans, particularly for diurnal species (Haddad and Giaretta 1999, Hödl and Amézquita 2001, de Sá et al. 2016, 2018). Although subject to some restrictions for message transfer (e.g., shorter range and higher light-dependence), visual signals have a lower energy cost than acoustic signals and can be as efficient as any other mode of short-range communication (Alcock 2013). Despite its high dependence on light, visual communication has been observed as a potentially relevant message transfer channel, even among nocturnal anuran species (Aho et al. 1988, Cummings et al. 2008, Gomez et al. 2009).

There may be a diversity of both visual and acoustic signals in some anuran families, and the social context must be considered when attempting to understand what is being communicated (Hödl and Amézquita 2001, Toledo et al. 2015). The selection of repertoires and signal use within them may differ according to context, such as courtship, male combat, or territorial maintenance. We know, for example, that males can modify their calls during closer interactions with conspecifics to protect their territories and ensure reproductive success, such as Acris blanchardi Harper, 1947 (Hylidae; Wagner Jr. 1992, Burmeister et al. 2002), Bokermannohyla ibitiguara (Cardoso, 1983) (Hylidae; Nali and Prado 2014), and Boana goiana (Lutz, 1968) (Hylidae; Morais et al. 2015). Also, recent studies reveal that associations among distinct communication modes are common (e.g., associations between acoustic and visual signals, or between tactile and visual signals) and these may transfer information more accurately. These synergistic associations represent multimodal communication and have been described for different anuran species, such as Engystomops pustulosus (Cope, 1864) (Leptodactylidae; Rosenthal et al. 2004), Crossodactylus schmidti Gallardo, 1961 (Hylodidae; Caldart et al. 2014), Hylodes japi de Sá, Canedo, Lyra, and Haddad, 2015 (Hylodidae; de Sá et al. 2016), and Hyperolius puncticulatus (Pfeffer, 1893) (Hyperoliidae; Starnberger et al. 2018).

Males of the treefrog genus Boana (Hylidae: Cophomantinae) typically possess morphological adaptations for physical confrontations (such as a spine on Finger I and hypertrophied arm muscles; Heyer et al. 1990) and exhibit aggressive and territorial behaviors. Indeed, de Sá et al. (2014) have already reported aggressiveness and territoriality for males of the nocturnal species Boana albopunctata (Spix, 1824). Although advertisement and territorial calls (Heyer et al. 1990, De La Riva et al. 1997, Kwet et al. 2002), and the visual signals-toe trembling, finger trembling, arm lifting, leg kicking, and vocal sac display (Toledo et al. 2007, Ramalho 2012, de Sá et al. 2014)—already have been described for this species, more detailed hypotheses about variation in the use of repertoires and synergistic associations of different signaling modes have yet to be explored. Much remains to be learned about both visual signaling in nocturnal anurans and multimodal signaling in anurans in general. Intensive efforts to collect data directly in the field and new approaches to explore signaling in anurans are needed to gather previous data from the literature and to improve our current knowledge, with the goal of informing our understanding of intraspecific communication in males of $B$. albopunctata in discrete social contexts. 
Based on field studies, we describe the repertoires of visual and acoustic signals, along with the associated contexts of each in Boana albopunctata. We specifically tested whether: (1) visual signals are directed toward opponents, as previously observed for diurnal anurans, or if they are associated with potential asymmetric morphologies; and (2) visual and acoustic signals are performed together, demonstrating mutual message reinforcement and an alerting function (previously proposed for other species; Moller and Pomiankowski 1993, Hebets and Papaj 2005, Preininger et al. 2009, Grafe et al. 2012) and multimodal signaling in nocturnal anurans.

\section{Materials and Methods}

\section{Study Site}

We performed the study in permanent and temporary flooded portions of the Cantaclaro Ranch (22¹9'36" S, 47²2'57" W; datum WGS 84), district of Itapé, municipality of Rio Claro, state of São Paulo in southeastern Brazil. The area is located in an ecotone between Cerrado (savannah vegetation) and Atlantic Forest (semideciduous seasonal forest). The current rural landscape contains zones of grazing and Eucalyptus plantations. The region has two wellestablished seasons-one wetter and hotter (rainy season), and the other drier and colder (dry season). The rainy season typically occurs from October-March, whereas the dry season occurs from April-September.

\section{Behavioral Data}

All behavioral data were obtained in the field by means of in-situ natural observations during the rainy season in a total of seven expeditions between 15 October 2015 and 10 March 2016. We started to collect data immediately after the sunset (when the males began calling) and stopped when the calling activity subsided or ceased completely. We video-recorded and audio-recorded calls using a Sony Cybershot
DSC-W270 video camera (Sony Corporation) with supplementary lighting (using headlamps with red filters, which minimize disturbance to the focal males) and a Marantz PMD-660 audio recorder (Sound United, LLC) equipped with a Sennheiser ME-66 unidirectional microphone (Sennheiser electronic GmbH \& Co. KG). The camera and microphone were positioned about $1.3 \mathrm{~m}$ from the calling male. We measured air temperature to standardize call recordings (Taigen et al. 1996, Guimarães and Bastos 2003, Wells 2010). We recorded and analyzed a total of $460 \mathrm{~min}$ of video and audio data (114 video files and 114 audio files).

\section{Repertoire of Visual Signals}

To identify the visual signals of Boana albopunctata, we randomly selected and observed 30 breeding males. We filmed each individual under natural conditions for $2 \mathrm{~min}(\mathrm{~N}$ $=30$ videos) without interfering with their behavior; the context of these recordings is termed "advertisement." Given that males $B$. albopunctata are territorial and remain at the same breeding site for months (de Sá et al. 2014), we chose distinct and well-spaced individuals to avoid duplication of frog recordings.

Data during "experimental territorial" contexts were gathered to understand the distinct use of signals (discussed in next section). We recorded all movements performed by resident males by watching all the video files generated and identifying visual signals that have been described in the literature (Hödl and Amézquita 2001, Hartmann et al. 2005). As defined in Hödl and Amézquita (2001), the following visual signaling behaviors included those that: (1) provide a visual cue during intraspecific interactions; (2) are redundant, conspicuous, and stereotyped; and (3) might provoke response by the conspecific receiver that will benefit the sender. We built the species repertoire of visual signals by concatenating the tabularized data, including the context in which each signal was performed. 


\section{Experimental Analysis of Visual Signals}

Some visual signals observed were directed to the right, to the left, or to both sides simultaneously-i.e., bilaterally. To detect whether males direct their visual signals toward an opponent, we conducted a field experiment with the same 30 males used for establishing the repertoire of visual signals. After the first $2 \mathrm{~min}$ of video recording under natural conditions, we inserted a conspecific male simulating an intruder in the territory of the resident male, with the "intruder male" being placed about $20 \mathrm{~cm}$ from resident male. As an intruder, we chose the first male randomly captured minutes before the experiment. We gently tied a nylon line to the waist of the intruder male to facilitate identification and move him wherever needed. We introduced the intruder in specific positions relative to the resident male: to his left side ( $N=$ 28 videos), to his right side ( $N=28$ videos $)$, and in front of $\operatorname{him}(N=28$ videos $)$. To minimize interference, we employed a 2 -min adaptation period from the introduction of the conspecific male to the beginning of the observations and video recordings of the resident male's behaviors. We observed and recorded each intruder position for $2 \mathrm{~min}$. We followed a random order for the positioning of the introduced conspecific male to avoid any potential bias. Experiments were classified as being in "territorial context."

We analyzed the video files obtained from the experimental trials following the same methods used for the construction of the repertoire of visual signals, with the addition of recording where the intruder was positioned with respect to the resident male. We tested whether resident males chose sides for signals that can be performed by distinct limbs independently, according to the intruder's position. For this we counted the number of times that each signal was performed on both sides simultaneously (frontal signal), only on the right side (right signal), and only on the left side (left signal). The frontal signal is likely detected by the intruder regardless of where the it was positioned, whereas the right signal is likely more detectable by an intruder placed to the right side of the signaler, and the left signal is likely to be detected by placing an intruder to the left of the resident male. We excluded arm lifting, face wiping, and leg kicking in this analysis because they were so rarely recorded. The vocal sac display was excluded because it is not a bilateral signal.

For all statistical analyses here and in the next sections we used BioEstat Version 5 software (Ayres et al. 2007). We conducted oneway ANOVA to investigate if there were significant differences between the frequency of visual signals performed on both sides simultaneously, only on the right side, or only on the left side. When we found significant differences, we ran a post-hoc Tukey test to investigate which specific groups differed.

To detect whether males direct their visual signals based on their body morphology, we verified potential morphological asymmetries (Dill 1977). We visited the Célio F. B. Haddad collection $(\mathrm{CFBH})$ in the Departamento de Biodiversidade, Instituto de Biociências of Universidade Estadual Paulista "Júlio de Mesquita Filho" (UNESP), Rio Claro, São Paulo state, Brazil, and measured males of $B$. albopunctata from the Cantaclaro Ranch and nearby localities $(N=20)$, as follow: 9 from Cantaclaro Ranch (CFBH 07438, 04144, 06052, 06673, 06676, 22088, 22090, 39114, and 39123); 2 from Floresta Estadual Edmundo Navarro de Andrade $\left(22^{\circ} 25^{\prime} \mathrm{S}, 4^{\circ} 33^{\prime} \mathrm{W}\right.$; datum WGS 84; 20 km NW Cantaclaro Ranch, municipality of Rio Claro, SP, Brazil) (CFBH 22084 and 38517); and 9 from Estação Ecológica de Itirapina $\left(22^{\circ} 13^{\prime} 10^{\prime \prime} \mathrm{S}\right.$, 4753'54" W; datum WGS 84; 22 km SE from ranch Cantaclaro, municipality of Itirapina, SP, Brazil) (CFBH 07059-07063, 38534, 38536, 38540, and 38541). We identified adult males by the presence of sexually dimorphic traits and measured morphological features based on Heyer et al. (1990) and Duellman (2001): finger and toe lengths, thigh length, tibia length, tarsus length, and foot length. A Student's t-test was 
used to evaluate the presence of morphological asymmetries in male B. albopunctata.

\section{Calls Repertoire}

We conducted audio recordings simultaneously with the video recordings described above to detect advertisement and agonistic call types of the same sample of 30 males. We analyzed the audio recordings with Raven Pro Version 1.4 software using a sampling frequency rate of 48 $\mathrm{kHz}$ and 16-bit resolution in the mono pattern (Center for Conservation Bioacoustics 2011). Concatenating all calls recorded, we distinguished and counted the advertisement and agonistic calls emitted by detecting notes A, B, and T (A and $\mathrm{B}$ as advertisement notes, and $\mathrm{T}$ as a territorial note; sensu Toledo et al. 2007); by associating the calls with each behavioral context (i.e., advertisement and territorial), we documented the acoustic repertoire of the species. We conducted a Friedman test to compare the numbers of $\mathrm{A}, \mathrm{B}$, and $\mathrm{T}$ notes performed in different contexts. All calls selected and analyzed were recorded at similar air temperatures $\left(27-30^{\circ} \mathrm{C}\right)$.

\section{Multimodal Signaling}

From all the video files analyzed, we assessed potential associations between visual and acoustic signals, and measured the intervals of transition between these two signaling modes when they were associated. Three types of association occurred, as follow: (1) visual signal performed immediately before a call; (2) visual signal performed immediately after a call; and (3) visual signal and call performed simultaneously. If the transition time between two distinct signaling modes was less than five seconds, we considered them to be associated. The vocal sac display was not included in this analysis because the studied males remained with the vocal sac inflated for long periods of time, including periods when they were not vocalizing (configurating a continuous visual signal). Face wiping and leg kicking signals were also not included in the statistical analysis (scarce samples for comparisons).

The total numbers of visual signals and multimodal signals were recorded to assess the relative importance of each. The average time of transition between signaling modes was calculated; the values obtained when visual signals preceded acoustic signals were compared with those obtained when visual signals followed acoustic signals. In the former case, we measured the amount of time from the end of the visual signal to the beginning of the acoustic signal, and in the latter case, we measured the amount of time from the end of the acoustic signal to the beginning of the visual signal. We applied Chisquare tests to verify whether there are significant preferences for performing both signal modes (visual and acoustic) simultaneously or asynchronously. For this test, we excluded data from arm lifting, arm wiping, and leg kicking (scarce samples). We applied the Wilcoxon matched-pairs test to determine whether there was a significant difference between the average transitional times between visual and acoustic modes, and vice-versa. By testing preferences and functions in multimodal signaling, we tested the propositions of mutual message reinforcement and of alerting function (Moller and Pomiankowski 1993, Hebets and Papaj 2005).

\section{Results}

\section{Repertoire of Visual Signals}

Male Boana albopunctata perform a variety of movements. We identified all the visual signals, as well as the primary occurrence of each visual signal relative to its frequency in discrete social contexts (Figure 1; Table 1). Toe trembling, finger trembling, arm lifting, leg lifting, face wiping, and vocal sac display are associated mainly in the context of advertisement, but also occur secondarily in the territorial context; leg kicking has a similar frequency in advertisement and territorial contexts. Vocal sac 
Table 1. Repertoire of visual signals for male Boana albopunctata $(N=30)$ with a description and the respective contexts of occurrence.

\begin{tabular}{|c|c|c|}
\hline Visual signal & Description & Context \\
\hline $\begin{array}{l}\text { Toe trembling } \\
(N=110)\end{array}$ & $\begin{array}{l}\text { Fast lifting or trembling of one or more toes } \\
\text { without a pattern. May be combined with } \\
\text { finger trembling }(N=49) \text {. }\end{array}$ & $\begin{array}{l}\text { Mainly advertisement, with } \\
\text { secondary occurrence in territorial } \\
\text { context. }\end{array}$ \\
\hline $\begin{array}{l}\text { Finger trembling } \\
(N=81)\end{array}$ & $\begin{array}{l}\text { Fast lifting or trembling of one or more fingers } \\
\text { without a pattern. May be combined } \\
\text { with toe trembling }(N=49) \text {. }\end{array}$ & $\begin{array}{l}\text { Mainly advertisement, with } \\
\text { secondary occurrence in territorial } \\
\text { context. }\end{array}$ \\
\hline $\begin{array}{l}\text { Arm lifting } \\
(N=19)\end{array}$ & $\begin{array}{l}\text { Fast and short lifting of an arm, with it not } \\
\text { passing above the head. May be combined } \\
\text { with leg lifting }(N=6) \text {. }\end{array}$ & $\begin{array}{l}\text { Mainly advertisement, with } \\
\text { secondary occurrence in territorial } \\
\text { context. }\end{array}$ \\
\hline $\begin{array}{l}\text { Leg lifting } \\
(N=60)\end{array}$ & $\begin{array}{l}\text { Fast and short lifting of a leg. It can be completely vertical } \\
\text { or laterally oriented }(N=3) \text {. May be combined with arm } \\
\text { lifting }(N=6) \text { or face wiping }(N=5) \text {. }\end{array}$ & $\begin{array}{l}\text { Mainly advertisement, with } \\
\text { secondary occurrence in territorial } \\
\text { context. }\end{array}$ \\
\hline $\begin{array}{l}\text { Face wiping } \\
(N=7)\end{array}$ & $\begin{array}{l}\text { Lifting of one arm and setting upon the head. } \\
\text { Similar to a head-whipping movement. } \\
\text { May precede leg lifting }(N=5) \text {. }\end{array}$ & $\begin{array}{l}\text { Mainly advertisement, with } \\
\text { secondary occurrence in territorial } \\
\text { context. }\end{array}$ \\
\hline $\begin{array}{l}\text { Leg kicking } \\
(N=4)\end{array}$ & $\begin{array}{l}\text { Fast and long movement of one leg. It is a } \\
\text { fast stretching with the return of the leg } \\
\text { to the initial position. }\end{array}$ & Territorial and advertisement. \\
\hline $\begin{array}{l}\text { Vocal sac display } \\
(N=25)\end{array}$ & $\begin{array}{l}\text { Vocal sac remains inflated between two } \\
\text { calls }(N=24) \text { or rarely when the male } \\
\text { was not calling }(N=1 \text {; Figure } 2) \text {. }\end{array}$ & $\begin{array}{l}\text { Mainly advertisement, with } \\
\text { secondary occurrence in territorial } \\
\text { context. }\end{array}$ \\
\hline
\end{tabular}

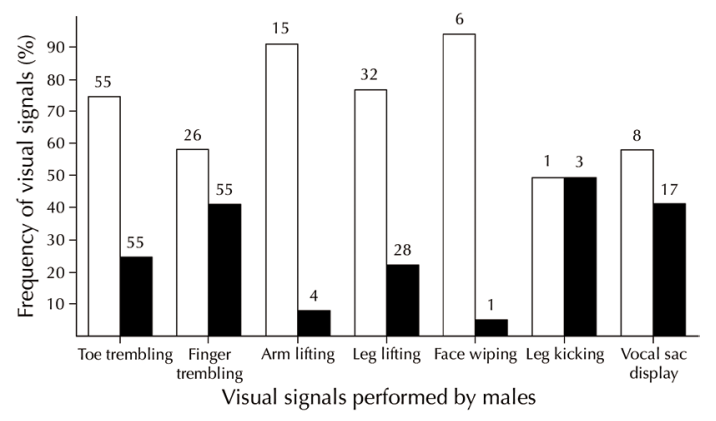

Figure 1. Frequency of visual signals performed by male Boana albopunctata in the field without the introduction of a conspecific male (advertisement context; white bars) and with the conspecific male (territorial context; black bars). The total number of records for each signal is indicated at the top of the bars, but frequencies (\%) from territorial contexts are divided by three to correct the three times longer recording in that context, and allowing comparison with frequencies from advertisement context. display (Figure 2) is not associated with any other visual signal. To estimate the main contexts in which each signal occurs, the frequencies of each signal performed in the territorial context were divided by three. Because recordings in the territorial context were three times longer than those in the advertisement context, we divided the territorial frequencies by three to bring the values into parity with one another.

\section{Direction of Visual Signals}

On 13 out of 30 occasions, the resident male Boana albopunctata became immobile and quiet during the entire period that the conspecific intruder was inside its territory. However, in the other 17 observations, we occasionally observed the resident frog to shift the orientation of his body when the intruder was present. Sometimes 


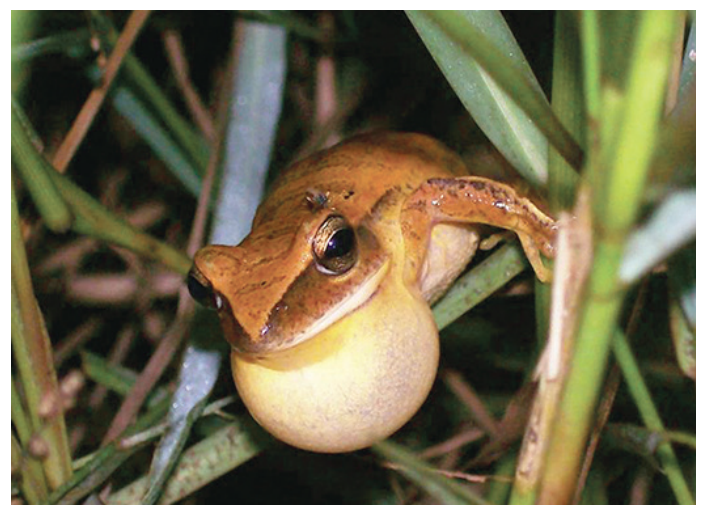

Figure 2. Male Boana albopunctata performing the vocal sac display.

the resident male turned its entire body to the side where the intruder was located $(N=4$, recorded in 2 males), whereas other times the resident male only turned its head toward the intruder ( $N=5$, recorded in 3 males). On two occasions, the resident male moved ahead and attacked the intruder. These three movements indicated some agonistic and territorial defense levels by the resident males. Moreover, twice the resident male was observed to jump and attack the intruder, which was obviously aggressive behavior associated with territorial defense. These responses indicate that resident males recognized the presence of the conspecific intruder and were bothered by the invasion of their territories.

We selected three visual signals to analyze intentional direction of visual signals by resident males-viz., toe trembling, finger trembling, and leg lifting. Toe trembling and finger trembling were performed more often with only the right foot or right hand, respectively, regardless of the location of the intruder (Figures 3, 4). Leg lifting was performed more often with only the left leg when the conspecific intruder was absent, but more often with the right leg when the intruder was present; these signals also were independent of the location of the intruder (Figure 5). According to a one-way ANOVA, the side of the frog's body used for the toe- and finger-trembling signals are significantly different $\{$ Toetrembling: $[\mathrm{F}(2,9)=4.979, p=0.035]$ and finger trembling $[\mathrm{F}(2,9)=12.679, p=0.028]\}$, whereas there is no significant difference for leg lifting $[\mathrm{F}(2,9)=1.653, p=0.244]$. A post-hoc Tukey test revealed significant differences between signals performed with the right side (most frequent) and with both sides simultaneously (least frequent) for toe trembling $(p<0.05)$ and for finger trembling $(p<0.01)$. The similarity of the sizes of all the right and the left fingers, toes, and forelimbs is statistically significant (Table 2).

\section{Calls Repertoire}

The calls of male Boana albopunctata are simple, having only one note per call (notes A, $\mathrm{B}$, or $\mathrm{T}$ ), and composite calls with two or more notes per call. We recorded the advertisement notes $\mathrm{A}$ and $\mathrm{B}$, and the territorial note $\mathrm{T}$ (sensu Toledo et al. 2007) more frequently in the composite calls than in the simple calls. Some common note combinations for the composite calls were AABT, ABB, ABT, and BBT. When used, note A was always the first note emitted and always emitted in composite calls, whereas note $\mathrm{T}$ was always the last. Both notes $\mathrm{A}$ and $\mathrm{B}$ have similar dominant frequencies, with $\mathrm{A}$ having $2.28 \mathrm{kHz} \pm 0.1(N=56 ; 2.06-2.43 \mathrm{kHz})$ and B having $2.35 \mathrm{kHz} \pm 0.1(N=33 ; 2.06-2.43$ $\mathrm{kHz}$ ). Nonetheless, the notes can be distinguished by their durations, with A lasting $0.37 \mathrm{~s} \pm 0.04$ $(N=56 ; 0.26-0.45 \mathrm{~s})$ and B lasting $0.56 \mathrm{~s} \pm 0.12$ $(N=33 ; 0.46-0.94 \mathrm{~s})$. Note that $\mathrm{T}$ is clearly differentiated audibly from notes $\mathrm{A}$ and $\mathrm{B}$ (note T: $N=14$; dominant frequency of $1.31 \mathrm{kHz} \pm$ 0.6 ; 0.19-2.25). Also, $\mathrm{T}$ has a different duration from note A (note $\mathrm{T}$ : $0.53 \mathrm{~s} \pm 0.08 ; 0.43-0.69 \mathrm{~s}$; $N=14)$. The number of notes $\mathrm{A}, \mathrm{B}$, and $\mathrm{T}$ emitted during distinct contexts (advertisement and territorial) is statistically similar [Note A $\chi^{2}$ $(1)=0.833 ; p=0.361$; Note B $\chi^{2}(1)=0.533 ; p$ $=0.465$; Note $\left.\mathrm{T} \chi^{2}(1)=0.133 ; p=0.715\right]$. Our results here confirmed the acoustic repertoire 


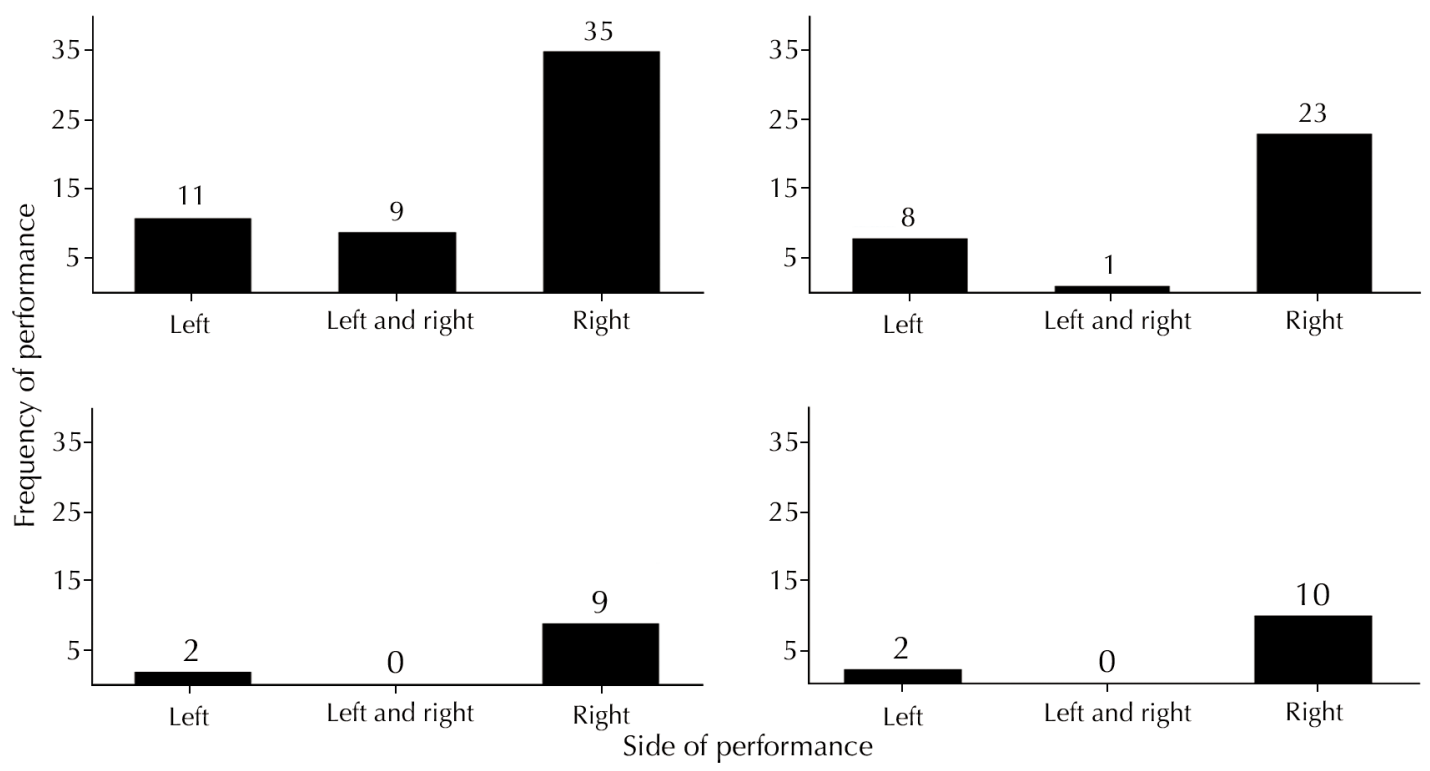

Figure 3. Frequency of performance of the toe-trembling signal according to side by male Boana albopunctata in discrete contexts, (A) without and with conspecific intruder male (B) in front, $(\mathbf{C})$ on the left, and (D) on the right side of the resident male. Signals were performed by the resident male using the left side, the left and right sides simultaneously, or the right side. The number of records for each direction is at the top of the bars.
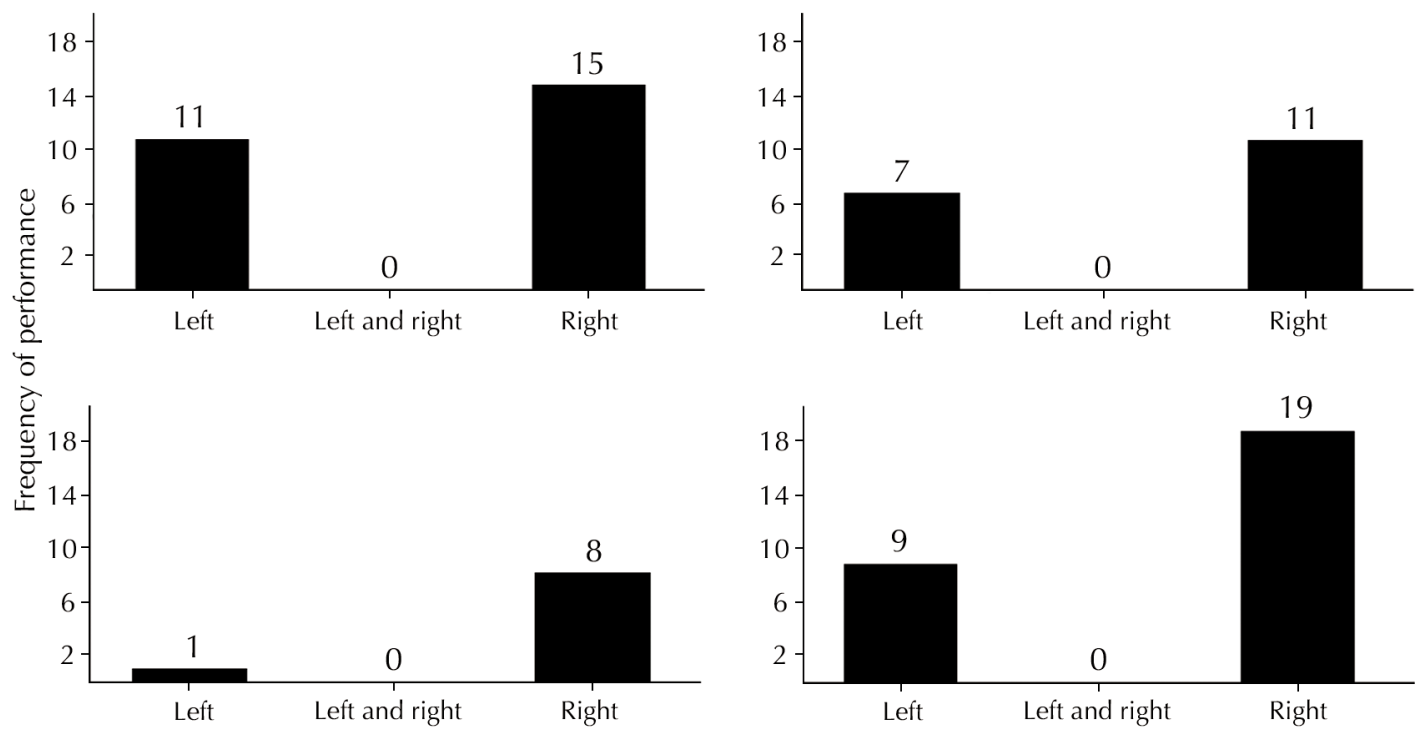

Side of performance

Figure 4. Frequency of performance of the finger-trembling signal according to side by male Boana albopunctata in distinct contexts, $(\mathbf{A})$ without and with conspecific intruder male $(\mathbf{B})$ in front, $(\mathbf{C})$ on the left, and $(\mathbf{D})$ on the right side of the resident male. Signals were performed by the resident male using the left side, the left and right sides simultaneously, or the right side. The number of records for each direction is at the top of the bars. 


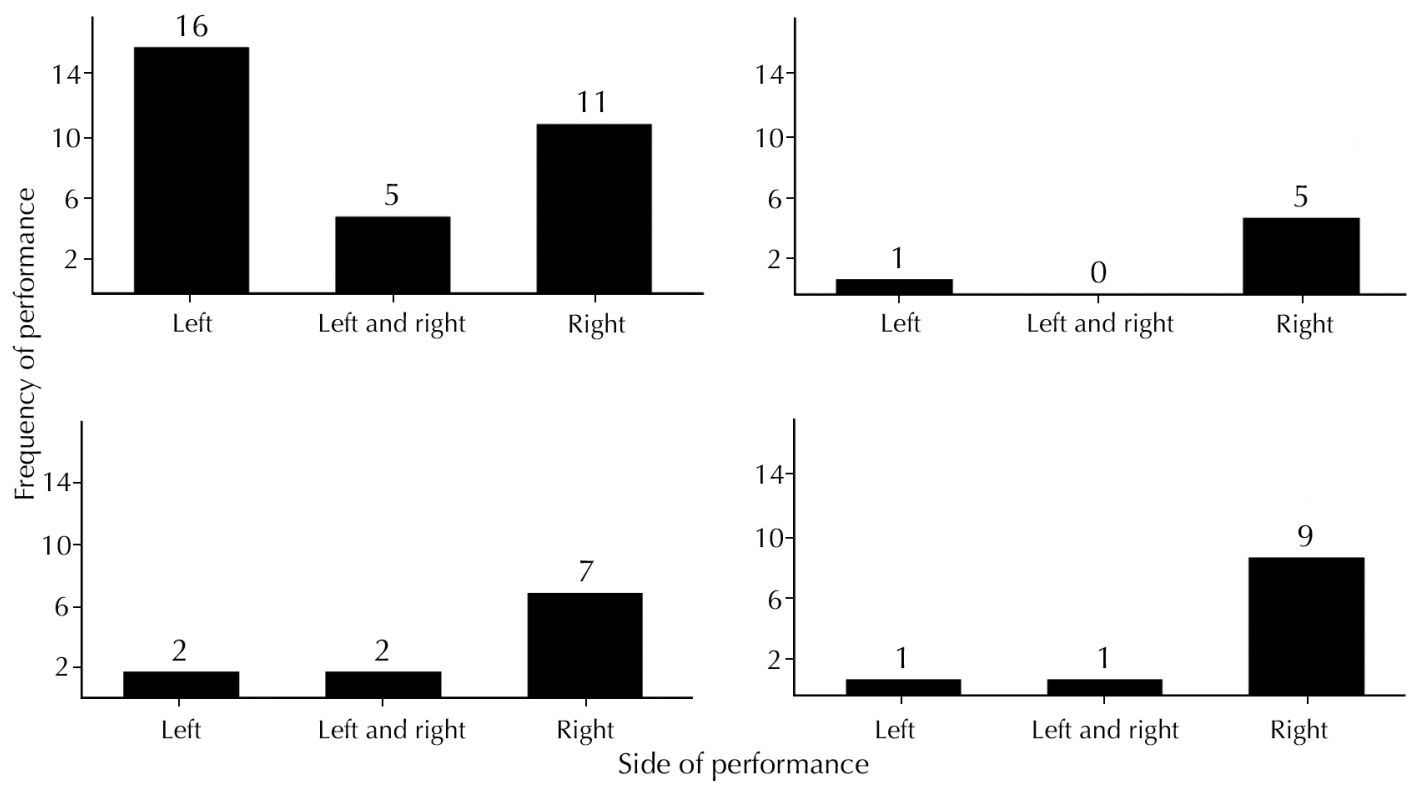

Figure 5. Frequency of performance of the leg lifting signal according to side by male Boana albopunctata in distinct contexts, (A) without and with conspecific intruder male (B) in front, $(\mathbf{C})$ on the left, and (D) on the right side of the resident male. Signals were performed by the resident male using the left side, the left and right side simultaneously, or the right side. The number of records for each direction is at the top of the bars.

described for the species (Haddad et al. 1988, Heyer et al. 1990, De la Riva et al. 1997, Kwet et al. 2002, Bastos et al. 2003, Toledo et al. 2007).

\section{Multimodal Signaling}

There is an association between visual and acoustic signaling modes (visual and acoustic), thereby documenting multimodal signaling. All visual signals that were considered part of the multimodal signaling were performed by resident males immediately prior to calling, immediately after calling, or while in the process of calling. The vocal sac display, as it is defined, was performed when the male was not calling as a pure visual signal (Figure 2); however, by necessity, it was also inflated during call emission, presenting a multimodal signal. The other visual signals recorded $(N=281$; Table 1$)$ often were performed in association with acoustic signals $(N=268)$. Therefore, around $95 \%$ of visual signals recorded were observed in association with acoustic signals, indicating a high degree of association between these two signaling modes (Figure 6).

There are statistically significant preferences for performing visual signals such as toe trembling, finger trembling, and leg lifting before or after calls based on Chi-square tests $\left[\chi^{2}(2, N\right.$ $=240)=9.836 ; p=0.007]$. The interval between both modes together with the number of transitions (visual to acoustic and vice-versa) corroborated the revealed preferences (Table 3). The numbers of visual signals preceding and following calls are about the same (Table 3). For all visual signals that were statistically analyzed, the transition intervals between signaling modes with visual signals preceding calls are significantly shorter than the intervals with visual signals being performed after calls (Figure 7; Table 4). 
Table 2. Measurements of fingers, toes, and forelimbs, and Student-t values from morphological asymmetry tests for male Boana albopunctata $(N=20)$. Vouchers are from Cantaclaro Ranch and nearby localities and are housed at Célio F. B. Haddad collection (CFBH) in the Departamento de Biodiversidade, Instituto de Biociências of Universidade Estadual Paulista (UNESP), Rio Claro, São Paulo state, Brazil. Separating traits bilaterally, average $(\mathrm{mm}) \mathrm{SD}$ values for morphological measurements are shown with $\mathrm{t}$ - and $p$-values from statistical comparisons. All morphological traits measured are statistically symmetric $(p>0.05)$.

\begin{tabular}{|c|c|c|c|c|}
\hline Trait & Left & Right & t & $p$ \\
\hline Finger I & $\begin{array}{ll}5.65 & 0.6\end{array}$ & $5.46 \quad 0.6$ & 0.966 & 0.34 \\
\hline Finger II & 6.340 .6 & 6.010 .6 & 1.587 & 0.121 \\
\hline Finger III & $\begin{array}{ll}8.1 & 0.87\end{array}$ & 7.830 .71 & 1.043 & 0.304 \\
\hline Finger IV & $\begin{array}{ll}6.78 & 0.8\end{array}$ & $\begin{array}{lll}6.22 & 0.8\end{array}$ & 1.943 & 0.06 \\
\hline Toe I & $\begin{array}{ll}5.08 & 0.7\end{array}$ & 5.380 .8 & 1.245 & 0.221 \\
\hline Toe II & $\begin{array}{ll}6.25 & 0.7\end{array}$ & 6.440 .9 & 0.716 & 0.479 \\
\hline Toe III & 91.2 & 91.2 & 0.164 & 0.871 \\
\hline Toe VI & 12.81 .4 & 12.51 .6 & 0.466 & 0.644 \\
\hline Toe V & $\begin{array}{ll}8.3 & 0.8\end{array}$ & 8.51 & 0.504 & 0.618 \\
\hline Thigh & $26.22 \quad 2.1$ & 25.92 & 0.427 & 0.672 \\
\hline Tibia & $27.28 \quad 2.1$ & 27.25 & 0.052 & 0.959 \\
\hline Tarsus & 16.251 .2 & 16.51 .4 & 0.535 & 0.596 \\
\hline Foot & 20.31 .8 & 19.91 .8 & 0.664 & 0.511 \\
\hline
\end{tabular}

Table 3. The number of transitions of visual signals performed before or after acoustic signals, and the number of visual signals performed simultaneously with acoustic calls. We also show average transition intervals between visual signals and acoustic signals performed by male Boana albopunctata ( SD; $N=30$ males).

\begin{tabular}{|c|c|c|c|c|c|}
\hline Visual signal & $\begin{array}{c}\text { Visual signal } \\
\text { performed before } \\
\text { call }(N)\end{array}$ & $\begin{array}{l}\text { Visual signal and } \\
\text { call performed } \\
\text { simultaneously }(N)\end{array}$ & $\begin{array}{l}\text { Visual signal } \\
\text { performed } \\
\text { after call }(N)\end{array}$ & $\begin{array}{l}\text { Time from } \\
\text { visual signal to } \\
\text { call (s) }\end{array}$ & $\begin{array}{l}\text { Time from } \\
\text { call to visual } \\
\text { signal (s) }\end{array}$ \\
\hline Toe trembling & $39 \%$ & $25 \%$ & $36 \%$ & 1.691 .3 & 2.331 .2 \\
\hline Finger trembling & $41 \%$ & $21 \%$ & $38 \%$ & 1.61 .3 & $2.65 \quad 1.2$ \\
\hline Arm lifting & $46 \%$ & $8 \%$ & $46 \%$ & 1.020 .7 & $2.36 \quad 1.3$ \\
\hline Leg lifting & $45 \%$ & $12 \%$ & $43 \%$ & 1.421 & 1.831 .1 \\
\hline Face wiping & $46 \%$ & 0 & $54 \%$ & $1.77 \quad 1.1$ & $\begin{array}{ll}1.78 & 0.1\end{array}$ \\
\hline Leg kicking & $57 \%$ & 0 & $43 \%$ & 1.661 .2 & 2.150 .8 \\
\hline
\end{tabular}


Table 4. Wilcoxon test (two tailed), matching pairs of transitions (s) from visual to acoustic signals and from acoustic to visual signals for male Boana albopunctata ( $N=30$ males). All results were statistically significant $(p<0.05)$, indicating that those time intervals are different.

\begin{tabular}{lccc}
\hline Visual signal & $\boldsymbol{Z}$ & $\boldsymbol{P}$ & $\boldsymbol{N}$ (pairs) \\
\hline Toe trembling & -2.912 & 0.004 & 57 \\
Finger trembling & -1.716 & 0.001 & 37 \\
Arm lifting & -2.49 & 0.013 & 11 \\
Leg lifting & -2.12 & 0.034 & 37 \\
\hline
\end{tabular}

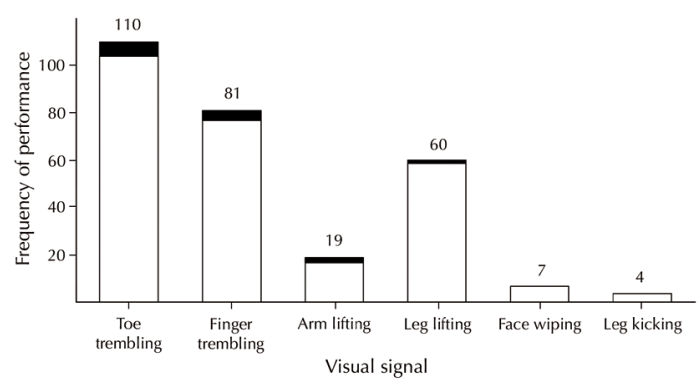

Figure 6. Frequency of visual signals recorded in association with calls for male Boana albopunctata ( $N=30$ males). White areas of the bars indicate the incidence of visual signals performed associated with calls and black areas indicate the incidence of visual signals not associated with calls. Numbers at the top of the bars indicate total frequency of performances for each visual signal.

\section{Discussion}

Visual Signaling for Boana albopunctata

Our total of seven visual signals constitutes the most complete repertoire of visual signals for male Boana albopunctata reported thus far. These include all signals previously recorded for this nocturnal treefrog (Toledo et al. 2007, Ramalho 2012, de Sá et al. 2014), with the addition of two newly recognized signals (leg lifting and face wiping), thereby improving the understanding of visual signaling by the species. We document that visual signaling by male $B$. albopunctata is more closely associated with advertisement than territorial contexts. Also, the observation that resident male frogs perform visual signals frequently in the absence of a conspecific intruder male further confirms that these stereotyped movements are true visual signals, not only a byproduct of some social excitement from visual detection.

Male Boana albopunctata do not direct their visual signals toward their conspecific receivers in territorial contexts. Overall, we found that the male frogs prefer to use their right sides to perform visual signals, regardless of the social context and the location of the intruder male. Our statistical analyses reveal that these preferences of sides are not associated with morphological asymmetries, in contrast from observations of Pseudacris regilla (Baird and Girard, 1852) (Hylidae; Dill 1977). As detected in the present study for $B$. albopunctata, preferential use of the right side has also been documented in other nocturnal frog species, such as Bufo bufo (Linnaeus, 1758) and Rhinella marina (Linnaeus, 1758) (Bufonidae; Bisazza et al. 1997, Robins et al. 1998). These reports coupled with the present study provide some insights into the evolution of brain lateralization among anurans, indicating that it might have a long evolutionary history, dating back to early tetrapods (Bisazza et al. 1997; Robins et al. 1998).

Behavioral studies of diurnal anuran species of the genera Hylodes and Micrixalus have demonstrated that individuals direct their visual signals toward their conspecific receivers (Preininger et al. 2013, de Sá et al. 2016). Male Hylodes japi, for example, perform visual signals by using their double vocal sacs independently, inflating either the right or left vocal sac depending on the location of the target conspecific (de Sá et al. 2016, Elias-Costa et al. 2017). Similarly, male Micrixalus saxicola (Jerdon, 1853) coordinate the use of their 


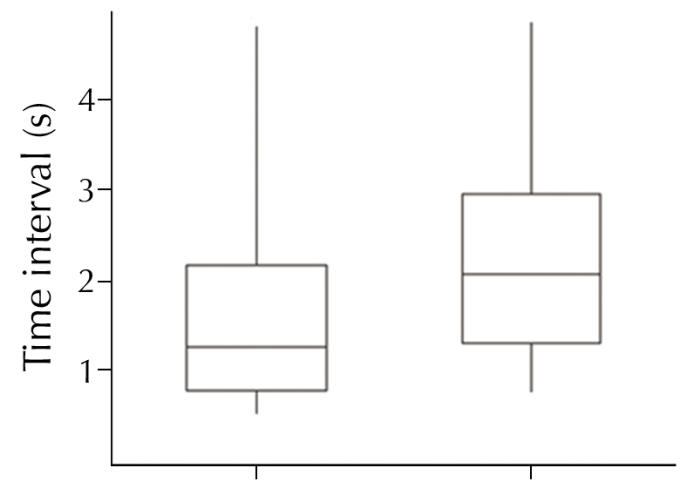

Visual signal before call Visual signal after call

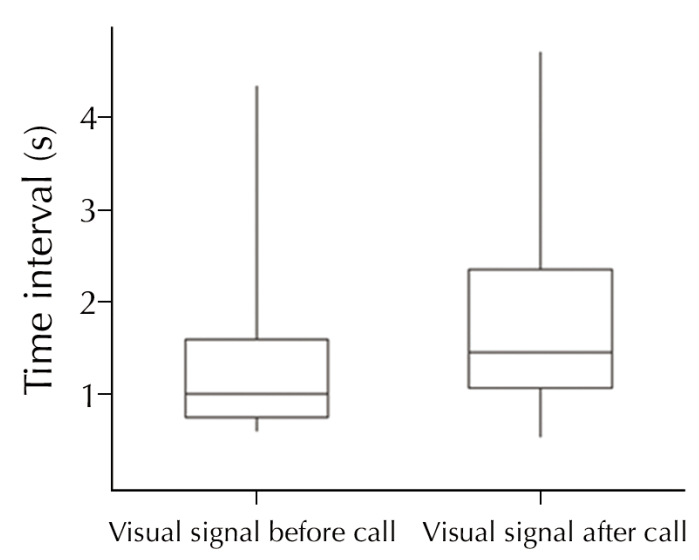

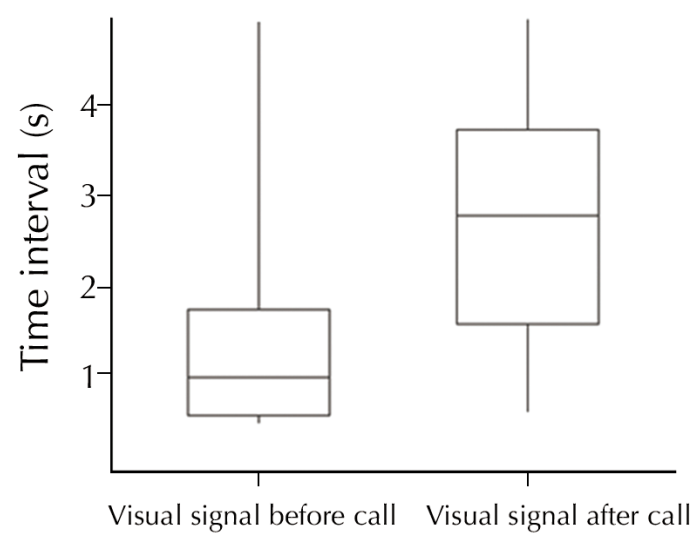

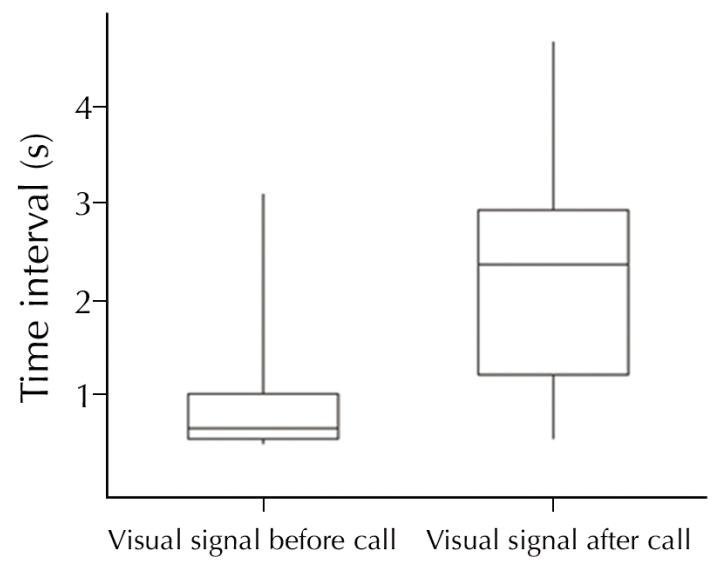

Figure 7. Time interval of transition from visual signals to calls and from calls to visual signals from the visual signals analyzed for resident male Boana albopunctata $(N=30$ males): (A) toe trembling $(N=57)$, (B) finger trembling $(N=37)$, $(\mathbf{C})$ leg lifting $(N=37)$, and $(\mathbf{D})$ arm lifting $(N=11)$. Box plots show the median, mean (line in the middle of the box), maximum, and minimum (vertical lines above and below) time interval.

forelimbs toward the position of a conspecific (Preininger et al. 2013). Although the directionality of visual signals is unknown in nocturnal species of hylids, these species commonly have relatively rich repertoires of visual signals (as shown here for B. albopunctata), suggesting some level of importance for these stereotyped movements during intraspecific communication (Hartmann et al. 2005, Toledo et al. 2007, Gomez et al. 2009). Moreover, visual signals in nocturnal hylids seem to function in attracting females, as reported for Aplastodiscus eugenioi (Carvalho-e-Silva and Carvalho-eSilva, 2005) (Hartmann et al. 2004), Boana curupi (Garcia, Faivovich, and Haddad, 2007) (Lipinski et al. 2012), and Scinax cardosoi (Carvalho-e-Silva and Peixoto, 1991; = Ololygon cardosoi) (Moroti et al. 2017). In addition, movements that produce visual signals also produce seismic signals (Narins 1990), especially 
when on high perches, with less stable substrates, such as breeding sites. For example, in the nocturnal frog Hyperolius puncticulatus, tapping signals produce vibrations on the substrates, acting in close-range signaling (Starnberger et al. 2018). Because daylight is believed to have facilitated the evolution of visual signaling among anurans (Hödl and Amézquita 2001), it is possible that diurnal species may have more accurate and highly developed visual signaling than nocturnal species; however, it does not exclude the possibility that visual communication has evolved in nocturnal anurans. Nocturnal habits do not provide a significant barrier to signal perception among anurans because they can see well in the dark (Kelber et al. 2017, Mohun and Davies 2019).

\section{Multimodal Signaling for a Nocturnal Anuran Species}

Our results show that associations between visual and acoustic signals are surprisingly frequent in male Boana albopunctata. We noted that males tend to perform visual signals immediately before or after emitting calls, rather than performing them while calling. There is less time between visual signals performed before the start of a call than between the end of the call and the start of visual signals performed following it. Frequently, male $B$. albopunctata combine visual and acoustic signals to form multicomponent signals, with visual signals functioning as alerts for the calls. According to Hebets and Papaj (2005), a first signaling mode gets the attention of the receiver for the subsequent and associated signaling mode, with the latter carrying a more important message. This synergistic combination of distinct signaling modes may reinforce the message sent by an emitter to a conspecific (Moller and Pomiankowski 1993).

Previous information on multimodal signaling (visual and acoustic) has been reported for B. albopunctata (Toledo et al. 2007, Ramalho 2012) and for other hylids with nocturnal habits, such as Aplastodiscus perviridis Lutz, 1950 and B. bischoffi (Boulenger, 1887) (Toledo et al. 2007), A. eugenioi, B. albomarginata, and Scinax eurydice (Bokermann, 1968) (Hartmann et al. 2005), and Hyla arborea (Linnaeus, 1758) (Gomez et al. 2009). Our findings open a new window of knowledge, better suggesting how visual signals might work for a nocturnal anuran. Visual signals in nocturnal anurans (likely more connected with advertisement contexts) may have a more subtle role, alerting and actually improving communication performed via calls. This possibility reinforces that in nocturnal anurans calls convey the main message during intraspecific communication, but it does not exclude an additional important communication role for visual signaling. As far as we know, we provide the first evidence that visual signals may have an alerting function among anurans (Moller and Pomiankowski 1993, Hebets and Papaj 2005). Similar tests as those conducted here have reported calls as the alerting message for subsequent visual signals among diurnal species of the genus Staurois (Grafe and Wanger 2007, Preininger et al. 2009, Grafe et al. 2012). Therefore, visual and acoustic signals may have distinct roles among diurnal and nocturnal anuran species, and the synergistic combination of visual and acoustic signals might have evolved differently, most likely affected by the presence or absence of daylight (Hödl and Amézquita 2001).

\section{Acknowledgments}

We thank J. S. Govone, F. Nalon Castro, and L. A. C. Silva for helping with the statistical analyses, and M. J. O. Campos, L. M. de Carvalho, and Mr. Alvino for providing access to the study site. We thank editors, J. Bertoluci and J. R. Downie, two anonymous reviewers, L. Trueb, and E. Wild for the valuable comments on an earlier version of the manuscript. We thank N. C. Pupin for support in the laboratory. For funding, A.R.L. and C.F.B.H. thank Conselho Nacional de Desenvolvimento Científico e Tecnológico 
(CNPq, grants \#306623/2018-8 and \#135813/20158), and C.F.B.H. and F.P.S. thank São Paulo Research Foundation (FAPESP, grants \#2013/50741-7 and \#2014/24972-4). F.P.S. also thanks Coordenação de Aperfeiçoamento de Pessoal de Nível Superior (CAPES - Finance Code 001). All of the procedures of this study were previously approved by Ethics Committee on Animal Use of Universidade Estadual Paulista (UNESP; approvals \#38/2015 and \#14/2016), Rio Claro, São Paulo, Brazil, and by Instituto Chico Mendes de Conservação da Biodiversidade/ Instituto Brasileiro do Meio Ambiente e dos Recursos Naturais Renováveis (ICMBio/IBAMA; approval \#47515-1).

\section{References}

Aho, A. C., K. Donner, C. Hydén, L. O. Larsen, and T. Reuter. 1988. Low retinal noise in animals with low body temperature allows high visual sensitivity. Nature 334: $348-350$.

Alcock, J. 2013. Animal Behavior: an Evolutionary Approach. Sunderland. Sinauer Associates. 605 pp.

Ayres, M., M. Ayres Jr., D. L. Ayres, and A. A. S. Santos. 2007. BioEstat. Aplicações Estatísticas nas Áreas das Ciências Biológicas e Médicas. Version 5. URL: https:// www.mamiraua.org.br.

Bastos, R. P., M. A. F. Bueno, S. L. Dutra, and L. P. Lima. 2003. Padrões de vocalização de anúncio em cinco espécies de Hylidae (Amphibia: Anura) do Brasil Central. Comunicação do Museu de Ciências e Tecnologia PUCRS, Série Zoologia 16: 39-51.

Bisazza, A., C. Cantalupo, A. Robins, L. J. Rogers, and G. Vallortigara. 1997. Pawedness and motor asymmetries in toads, laterality: asymmetries of body, brain and cognition. Laterality 2: 49-64.

Blair, W. F. 1958. Mating call in the speciation of anuran amphibians. American Naturalist 92: 27-51.

Brunetti, A. E., C. Taboada, and J. Faivovich. 2014. The reproductive biology of Hypsiboas punctatus (Anura: Hylidae): male territoriality and the possible role of different signals during female choice. Salamandra 50: 215-224.

Burmeister, S. S., A. G. Ophir, M. J. Ryan, and W. Wilczynski. 2002. Information transfer during cricket frog contests. Animal Behaviour 64: 715-725.
Caldart, V. M., S. Iop, and S. Z. Cechin. 2014. Social interactions in a Neotropical stream frog reveal a complex repertoire of visual signals and the use of multimodal communication. Behaviour 151: 719-739.

Center for Conservation Bioacoustics. 2011. Raven Pro. Interactive sound analysis software. Version 1.4. URL: https://ravensoundsoftware.com.

Chuang, M.-F., Y. C. Kam, and M. A. Bee. 2017. Territorial olive frogs display lower aggression towards neighbours than strangers based on individual vocal signatures. Animal Behaviour 123: 217-228.

Cummings, M. E., X. E. Bernal, R. Reynaga, A. S. Rand, and M. J. Ryan. 2008. Visual sensitivity to a conspicuous male cue varies by reproductive state in Physalaemus pustulosus females. Journal of Experimental Biology 211: 1203-1210.

De la Riva, I., R. Márquez, and J. Bosch. 1997. Description of the advertisement calls of some South American Hylidae (Amphibia: Anura): taxonomic and methodological consequences. Bonner Zoologische Beiträge 47: $175-185$.

de Sá, F. P., J. Zina, and C. F. B. Haddad. 2014. Reproductive dynamics of the Neotropical treefrog Hypsiboas albopunctatus (Anura, Hylidae). Journal of Herpetology 48: 181-185.

de Sá, F. P., J. Zina, and C. F. B. Haddad. 2016. Sophisticated communication in the Brazilian torrent frog Hylodes japi. PLOS ONE 11: e0145444.

de Sá, F.P., N. C. Pupin, and C. F. B. Haddad. 2018. Notes on agonistic communication by the Neotropical torrent frog Hylodes meridionalis (Hylodidae). Herpetology Notes 11: 919-923.

Dill, L. M. 1977. 'Handedness' in the Pacific tree frog (Hyla regilla). Canadian Journal of Zoology 55: 1926-1929.

Doherty, J. A. and H. C. Gerhardt. 1983. Hybrid tree frogs: vocalizations of males and selective phonotaxis of females. Science 220: 1078-1080.

Duellman, W. E. 2001. The Hylid Frogs of Middle America. $2^{\text {nd }}$ Edition. Society for the Study of Amphibians and Reptiles. Contributions to Herpetology 18. 442 pp.

Elias-Costa, A. J., R. Montesinos, T. Grant, and J. Faivovich. 2017. The vocal sac of Hylodidae (Amphibia, Anura): phylogenetic and functional implications of a unique morphology. Journal of Morphology 278: 15061516.

Gerhardt, H. C. 1994. The evolution of vocalization in frogs and toads. Annual Review of Ecology and Systematics 25: $293-324$. 
Gomez, D., C. Richardson, T. Lengagne, S. Plenet, P. Joly, J. P. Léna, and M. Théry. 2009. The role of nocturnal vision in mate choice: females prefer conspicuous males in the European tree frog (Hyla arborea). Proceedings of the Royal Society B, Biological Sciences 276: 23512358.

Grafe, T. U. and T. C. Wanger. 2007. Multimodal signaling in male and female foot-flagging frogs Staurois guttatus (Ranidae): an alerting function of calling. Ethology 113: 772-781.

Grafe, T. U., D. Preininger, M. Sztatecsny, R. Kasah, J. M. Dehling, S. Proksch, and W. Hödl. 2012. Multimodal communication in a noisy environment: a case study of the Bornean rock frog Staurois parvus. PLoS ONE 7: e37965.

Grenat, P. R., J. A. Valetti, and A. L. Martino. 2013. Intraspecific variation in advertisement call of Odontophrynus cordobae (Anura, Cycloramphidae): a multilevel and multifactor analysis. Amphibia-Reptilia 34: 471-482.

Guimarães, L. dall'A. and R. P. Bastos. 2003. Vocalizações e interações acústicas em Hyla raniceps (Anura, Hylidae) durante a atividade reprodutiva. Iheringia, Série Zoologia 93: 149-158.

Haddad, C. F. B. and A. A. Giaretta. 1999. Visual and acoustic communication in the Brazilian torrent frog, Hylodes asper (Anura: Leptodactylidae). Herpetologica 55: 324-333.

Haddad, C. F. B., G. V. Andrade, and A. J. Cardoso. 1988. Anfíbios anuros no Parque Nacional da Serra da Canastra, estado de Minas Gerais. Brasil Florestal 64: 9-20.

Hartmann, M. T., P. A. Hartmann, and C. F. B. Haddad. 2004. Visual signaling and reproductive biology in a nocturnal treefrog, genus Hyla (Anura: Hylidae). Amphibia-Reptilia 25: 395-406.

Hartmann, M. T., L. O. M. Giasson, P. A. Hartmann, and C. F. B. Haddad. 2005. Visual communication in Brazilian species of anurans from the Atlantic forest. Journal of Natural History 39: 1675-1685.

Hebets, E. A. and D. R. Papaj. 2005. Complex signal function: developing a framework of testable hypotheses. Behavioral Ecology and Sociobiology 57: $197-214$.

Heyer, W. R., A. S. Rand, C. A. G. da Cruz, O. L. Peixoto, and C. E. Nelson. 1990. Frogs of Boracéia. Arquivos de Zoologia, Museu de Zoologia da Universidade de São Paulo 31: 231-410.

Hödl, W. and A. Amézquita. 2001. Visual signaling in anuran amphibians. Pp. 121-141 in M. J. Ryan (ed.),
Anuran Communication. Washington. Smithsonian Institution Scholarly Press.

Kelber, A., C. Yovanovich, and P. Olsson. 2017. Thresholds and noise limitations of colour vision in dim light. Philosophical Transactions of the Royal Society B, Biological Sciences 372: 20160065.

Kwet, A., M. Solé, T. Miranda, J. Melchiors, D. E. Naya, and R. Maneyro. 2002. First record of Hyla albopunctata Spix, 1824 (Anura: Hylidae) in Uruguay, with comments on the advertisement call. Boletín de la Asociación Herpetológica Española 13: 15-19.

Lipinski, V. M., V. M. Caldart, and S. Iop. 2012. Visual communication in Hypsiboas curupi (Anura: Hylidae) at Parque Estadual do Turvo, southern Brazil. Phyllomedusa 11: 71-74.

Mohun, S. M. and W. I. L. Davies. 2019. The evolution of amphibian photoreception. Frontiers in Ecology and Evolution 7: 321.

Moller, A. P. and A. Pomiankowski. 1993. Why have birds got multiple sexual ornaments? Behavioral Ecology and Sociobiology 32: 167-176.

Morais, A. R., M. N. Siqueira, and R. P. Bastos. 2015. How do males of Hypsiboas goianus (Hylidae: Anura) respond to conspecific acoustic stimuli? Zoologia 32: $431-437$.

Moroti, M. T., M. Pedrozo, G. Sestito, and D. J. Santana. 2017. First record of visual displays in Scinax cardosoi (Anura: Hylidae). Phyllomedusa 16: 283-287.

Nali, R. C. and C. P. A. Prado. 2014. Complex call with different messages in Bokermannohyla ibitiguara (Anura, Hylidae), a gladiator frog of the Brazilian Cerrado. Journal of Herpetology 48: 407-414.

Narins, P. M. 1990. Seismic communication in anuran amphibians. Bioscience 40: 268-274.

Preininger, D., M. Boeckle, and W. Hödl. 2009. Communication in noisy environments II: visual signaling behavior of male foot-flagging frogs Staurois latopalmatus. Herpetologica 65: 166-173.

Preininger, D., M. J. Stiegler, K. V. Gururaja, S. P. Vijayakumar, V. R. Torsekar, M. Sztatecsny, and W. Hödl. 2013. Getting a kick out of it: multimodal signalling during male-male encounters in the footflagging frog Micrixalus aff. saxicola from the Western Ghats of India. Current Science 12: 1735-1740.

Ramalho, C. E. S. 2012. Interações sociais em Hypsiboas albopunctatus (Anura, Hylidae): os contextos da comunicação acústica e visual. Unpublished M.Sc. Dissertation. Universidade Estadual Paulista, Rio Claro, SP, Brazil. 
Robins, A., G. Lippolis, A. Bisazza, G. Vallortigara, and L. J. Rogers. 1998. Lateralized agonistic responses and hindlimb use in toads. Animal Behaviour 56: 875-881.

Rosenthal, G. G., A. S. Rand, and M. J. Ryan. 2004. The vocal sac as a visual cue in anuran communication: an experimental analysis using video playback. Animal Behaviour 68: 55-58.

Starnberger, I., P. M. Maier, W. Hödl, and D. Preininger. 2018. Multimodal signal testing reveals gestural tapping behavior in spotted reed frogs. Herpetologica 74: 127 134.

Taigen, T. L., J. A. O'Brien, and K. D. Wells. 1996. The effect of temperature on calling energetics of the spring peeper (Pseudacris crucifer). Amphibia-Reptilia 17: $149-158$.
Toledo, L. F., O. G. Araújo, L. D. Guimarães, R. Lingnau, and C. F. B. Haddad. 2007. Visual and acoustic signaling in three species of Brazilian nocturnal tree frogs (Anura, Hylidae). Phyllomedusa 6: 61-68.

Toledo, L. F., I. A. Martins, D. P. Bruschi, M. A. Passos, C. Alexandre, and C. F. B. Haddad. 2015. The anuran calling repertoire in the light of social context. Acta Ethologica 18: 87-99.

Wagner Jr., W. E. 1992. Deceptive or honest signalling of fighting ability? A test of alternative hypotheses for the function of changes in call dominant frequency by male cricket frogs. Animal Behaviour 44: 449-462.

Wells, K. D. 2010. The Ecology and Behavior of Amphibians. Chicago. University of Chicago Press. 1148 pp.

Editor: J. Roger Downie 